\title{
Fluorescence Enhancement Detection of Underivatized Amino Acids Using a Trifluoroacetophenone-Based Tripodal Fluoroionophore
}

\author{
Shin-ichi Sasakia , Gou Monma, Daniel Citterio, Koji Yamada, and Koji Suzuki ${ }^{\star}$
}

\begin{abstract}
A tripodal fluoroionophore based on a hexasubstituted benzene unit having two trifluoroacetophenone groups and a pyrenyl moiety was synthesized, and its characteristics as fluorogenic reagent or component of an ISE or optode membrane towards several underivatized amino acids were examined. In a solid-liquid extraction experiment in acetonitrile, the fluorescence enhancement response was observed in the order of Phe, Cys, and Gly. On the other hand, the PVC-based polymeric membrane applied in ISE showed Phe selectivity with a monoanionic Nernstian response, supporting the assumption that the ionophore binds Phe in its anionic form. It is demonstrated that the optode membrane based on this fluoroionophore shows fluorescence enhancement response towards Phe or Cys in a flow-system.
\end{abstract}

Keywords: Amino acids $\cdot$ Ionophore $\cdot$ ISE $\cdot$ Optode $\cdot$ Trifluoroacetophenone

\section{Introduction}

With application to chemical sensors in mind, the design and synthesis of artificial receptors/ionophores for the selective recognition of biologically important species has been actively studied [1-4]. However, compared to the large number of chromo/ fluororeceptors for cations and anions, the development of artificial receptors for amino acids is quite limited and still a challenging theme due to their highly hydrophilic character. Amino acids exist as the zwitter ionic form in the solid state and as an equi-

${ }^{*}$ Correspondence: Prof. K. Suzuk Department of Applied Chemistry Keio University, 3-14-1 Hiyoshi, Kohoku-ku Yokohama 223-8522, Japan

Tel.: +8145566 1568

Fax: +81 455645095

E-Mail: Suzuki@applc.keio.ac.jp

aPresent address:

Dept. Bioscience and Biotechnology

Faculty of Science and Engineening

Ritsumeikan University, 1-1-1 Nojihigashi

Kusatsu, Shiga 525-8577, Japan librium between cationic and anionic form in solution depending on their $\mathrm{pK}_{\mathrm{a}}$ and the surrounding $\mathrm{pH}$. Although lipophilic amino acid esters rather than underivatized amino acids have been studied in most cases, recent reports focus on determination of free amino acids in view of more practical use. These reports include some basic studies of amino acid sensing [5-12], reagents for spectrometric recognition by colorimetry [13-16], fluorescence [17-23], and circular dichroism spectral changes [24-26], or application to chemical sensors such as ion-selective electrodes (ISEs) [27-29] and optodes [30]. We have recently demonstrated that well-designed trifluoroacetophenone derivatives including compound 1 are applicable to ISEs as ionophores for the determination of phenylalanine with a monoanionic Nernstian response [29]. Trifluoroacetophenone is known to form adducts with amines [31-34] or alcohols [35], and almost all ISEs for carbonate sensing utilize trifluoroacetophenone derivatives as ionophores [36][37]. To bind the amino and the carboxylate groups of an amino acid in the anionic form simultaneously, more than one trifluoroacetophenone group should be included in one molecule. Therefore, the combination of two of those functional groups with a fluorescence reporter moiety in the same molecule would lead to an optical sensing material such as a fluorometric reagent or ionophore for optodes for anionic form amino acid sensing. Furthermore, tripodal structures based on a hexasubstituted benzene ring [38] as a spacer have been used to construct effective anion receptors [39-42] and were successfully applied to chemical sensors [43-45]. Based on this molecular design concept, we synthesized a new tripodal fluoroionophore $\mathbf{2}$ having two trifluoroacetophenone groups and a pyrenyl group in the 2,4,6-positions of the spacer benzene ring (Fig. 1). Here we report on the characteristics of $\mathbf{2}$ as ionophore in ISE and in an optode.

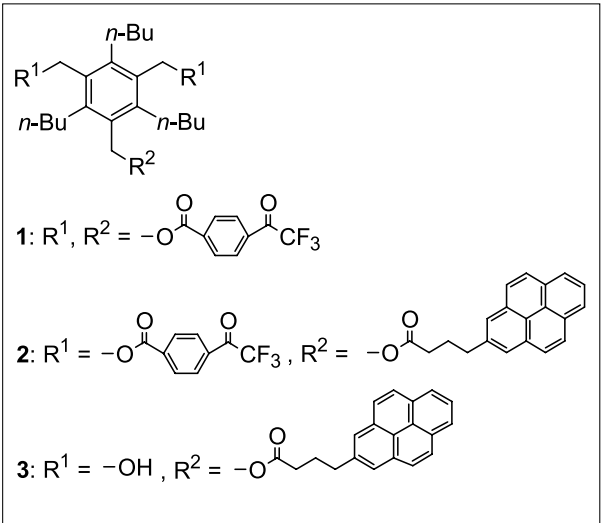

Fig. 1. Chemical structures of tripodal ionophore 1, fluoroionophore 2 and its synthetic precursor 3 


\section{Experimental}

\subsection{Materials}

The highest grade commercially available reagents were used for the preparation of the test buffer solutions. The distilled and deionized water used had a resistivity of greater than $1.5 \times 10^{7} \Omega \mathrm{cm}$ at $25^{\circ} \mathrm{C}$. $o$-Nitrophenyl octyl ether (o-NPOE) was purchased from Dojindo Laboratories $(\mathrm{Ku}-$ mamoto, Japan). o-Cynanophenyl octyl ether (o-CPOE) was purchased from Fluka (Buchs, Switzerland). Tridodecylmethylammonium chloride (TDDMACl) was purchased from Aldrich (Milwaukee, WI). Poly(vinyl chloride) (high molecular weight type) was obtained from Sigma Chemical Co. (St. Louis, MO). 1-Pyrenebutyric acid was purchased from Tokyo Kasei Kogyo Co. (Tokyo, Japan). 4-Trifluoroacetylbenzoyl chloride was prepared according to a literature procedure [46]. 1,3,5-Tributyl2,4,6-tris(hydroxymethyl)benzene was prepared as previously reported [29]. THF was distilled over sodium benzophenone ketyl prior to use. Other solvents and reagents for the synthesis were used as purchased without further purification. All moisturesensitive reactions were carried out under an atmosphere of nitrogen.

\subsection{Instruments}

${ }^{1} \mathrm{H}-\mathrm{NMR}$ spectra were recorded on a JEOL JNM-LA 300 spectrometer in $\mathrm{CDCl}_{3}$ and all chemical shifts are relative to an internal standard of tetramethylsilane. ESI-MS spectra were recorded on a PerSeptive Biosystems Mariner ${ }^{\mathrm{TM}}$ spectrometer with $\mathrm{MeOH}$ as an eluent. Recycling HPLC separation was undertaken using two $600-\mathrm{mm} \times 25$-mm GPC columns (Shodex GPC H2001L, Shodex GPC H2002L, Showa Denko, Tokyo, Japan) with $\mathrm{CHCl}_{3}$ as an eluent. The absorption spectra were recorded on a Hitachi U-2001 doublebeam spectrophotometer (Hitachi Co. Ltd., Tokyo, Japan). The fluorescence emission spectra were measured on a Hitachi F-4500 spectrophotometer using a standard fluorescence quartz cell $(1 \mathrm{~cm} \times 1 \mathrm{~cm})$ in solution or a custom made flow-through cell for mounting optode membranes.

\subsection{Electrode Preparation and emf Measurements}

The PVC matrix-based membranes were prepared from a mixture composed of $3 \mathrm{wt} \%$ ionophore, $64.7 \mathrm{wt} \% o$-NPOE, $32.3 \mathrm{wt} \% \mathrm{PVC}$, and $50 \mathrm{~mol} \%$ (relative to the ionophore) TDDMACl. The cocktail components dissolved in THF were poured into a vial and placed on a hot plate. Slow evaporation of THF at $40{ }^{\circ} \mathrm{C}$ gave ion-sensitive membranes of about $100 \mu \mathrm{m}$ thickness. A $6 \mathrm{~mm}$ diameter circle was cut from a prepared membrane and placed on the tip of a PVC ion-selective electrode body as- sembly (Liquid Electrode Membrane Kit, DKK Co. Ltd., Tokyo, Japan). The external reference electrode was a double-junctiontype $\mathrm{Ag}-\mathrm{AgCl}$ electrode (HS-305DS, Toa Electronics Ltd., Tokyo, Japan). The electrode potential (emf) measurements were performed at $25^{\circ} \mathrm{C}$ using the electrochemical cell system: $\mathrm{Ag}|\mathrm{AgCl}|$ saturated $\mathrm{KCl}$ $0.3 \mathrm{M} \mathrm{NH}_{4} \mathrm{NO}_{3} \|$ buffered sample solution | ISE membrane $|0.1 \mathrm{M} \mathrm{NaCl}| \mathrm{AgCl} \mid \mathrm{Ag}$.

All sample solutions were prepared with $0.1 \mathrm{M}$ Tris- $\mathrm{H}_{2} \mathrm{SO}_{4}$ buffer solution at $\mathrm{pH}$ 8.6. The selectivity coefficients $K \mathrm{i}, \mathrm{j}{ }^{\mathrm{Pot}}$, where i stands for the primary ion (anionic form of phenylalanine) and $\mathrm{j}$ for the interfering ion, were calculated from the response potentials using the separate-solution method (SSM; $[\mathrm{i}]=[\mathrm{j}]=0.1 \mathrm{M})$ according to the recommendations of IUPAC [47] and JIS [48].

\subsection{Ion Optode Membrane}

The optode membrane was prepared from a mixture composed of $2 \mathrm{wt} \%$ fluoroionophore 2, $58.8 \mathrm{wt} \% o$-CPOE, $39.2 \mathrm{wt} \% \mathrm{PVC}$ and $50 \mathrm{~mol} \%$ (relative to the ionophore) TDDMACl. A total of $200 \mathrm{mg}$ of those components was dissolved in $2 \mathrm{ml}$ of THF, and 0.2 $\mathrm{ml}$ of this cocktail solution was dropped on a quartz plate. It was rotated at $600 \mathrm{rpm}$ for 5 sec using a spin-coater (1H-D3, Mikasa Co. Ltd.) to give an ion optode membrane, which was subjected to fluorescence measurement in a flow-through system.

\subsection{Synthesis of Fluoroionophore 2}

A suspension of 1-pyrenebutylic acid (292 mg, $1.0 \mathrm{mmol}$ ) in $15 \mathrm{ml}$ of $\mathrm{CH}_{2} \mathrm{Cl}_{2}$ was placed in an ice-salt bath, and triethylamine (202 mg, $2.0 \mathrm{mmol}$ ) and benzotriazol-1yloxy-tris(dimethylamino)-phosphonium hexafluorophosphate (BOP, $671 \mathrm{mg}, 1.5$ mmol) in $5 \mathrm{ml}$ of $\mathrm{CH}_{2} \mathrm{Cl}_{2}$ was added. After stirring for $30 \mathrm{~min}, 1,3,5$-tributyl-2,4,6tris(hydroxymethyl)benzene $\quad(342 \mathrm{mg}$, $1.0 \mathrm{mmol}$ ) in $10 \mathrm{ml}$ of $\mathrm{CH}_{2} \mathrm{Cl}_{2}$ was added dropwise, and the mixture was stirred for $1 \mathrm{~d}$ at room temperature. It was poured into water and extracted three times with $\mathrm{CH}_{2} \mathrm{Cl}_{2}$. The combined organic phase was washed with sat. aq. $\mathrm{NaHCO}_{3}$ and brine, dried over anhydrous $\mathrm{Na}_{2} \mathrm{SO}_{4}$, filtered, and concentrated. The crude product was purified by chromatography on silica gel $\left(\mathrm{CH}_{2} \mathrm{Cl}_{2}\right.$-AcOEt 9:1) to give $234 \mathrm{mg}(38 \%)$ of intermediate 3. $\lambda_{\text {max }} / \mathrm{nm}\left(\mathrm{CH}_{3} \mathrm{CN}\right)(\varepsilon /$ $\left.\mathrm{M}^{-1} \mathrm{~cm}^{-1}\right): 264$ (27200), 275 (51500), 312 (12600), 325 (30200), 341 (44600); ${ }^{1} \mathrm{H}$ NMR: $\delta=0.92\left(6 \mathrm{H}, \mathrm{t}, J=7 \mathrm{~Hz}, \mathrm{CH}_{3}\right), 0.98$ $\left(3 \mathrm{H}, \mathrm{t}, J=7 \mathrm{~Hz}, \mathrm{CH}_{3}\right), 1.39-1.52(12 \mathrm{H}, \mathrm{m}$, $\mathrm{ArCH}_{2} \mathrm{CH}_{2} \mathrm{CH}_{2}$ ), 2.20 (2H, quintet, $J=8$ $\left.\mathrm{Hz}, \mathrm{Py}-\mathrm{CH}_{2} \mathrm{CH}_{2}\right), 2.48(2 \mathrm{H}, \mathrm{t}, J=8 \mathrm{~Hz}$, $\left.\mathrm{OCOCH}_{2}\right), 2.75-2.80\left(4 \mathrm{H}, \mathrm{m}, \mathrm{ArCH}_{2} \mathrm{CH}_{2}\right)$, 2.85-2.91 (2H, m, $\left.\mathrm{ArCH}_{2} \mathrm{CH}_{2}\right), 3.39(2 \mathrm{H}, \mathrm{t}$, $\left.J=8 \mathrm{~Hz}, \mathrm{Py}-\mathrm{CH}_{2}\right), 4.73\left(4 \mathrm{H}, \mathrm{s}, \mathrm{ArCH}_{2} \mathrm{OH}\right)$, $5.23\left(2 \mathrm{H}, \mathrm{s}, \mathrm{ArCH} \mathrm{H}_{2} \mathrm{OCO}\right), 7.83(1 \mathrm{H}, \mathrm{d}, J=$ $8 \mathrm{~Hz}, P y), 7.96-8.17(7 \mathrm{H}, \mathrm{m}, P y), 8.26(1 \mathrm{H}$, $\mathrm{d}, J=9 \mathrm{~Hz}, P y)$; ESI-MS $629\left(\mathrm{M}+\mathrm{Na}^{+}\right)$.
To a solution of $3(92 \mathrm{mg}, 0.15 \mathrm{mmol})$ in $5 \mathrm{ml}$ of $\mathrm{CH}_{2} \mathrm{Cl}_{2}$ was added triethylamine (53 mg, $0.52 \mathrm{mmol}$ ) and 4-trifluoroacetylbenzoyl chloride ( $88 \mathrm{mg}, 0.37 \mathrm{mmol}$ ) in 5 $\mathrm{ml}$ of $\mathrm{CH}_{2} \mathrm{Cl}_{2}$, and the mixture was stirred for $12 \mathrm{~h}$ at room temperature. The reaction mixture was then poured into $5 \%$ aq. $\mathrm{HCl}$ and extracted three times with $\mathrm{CH}_{2} \mathrm{Cl}_{2}$. The combined organic phase was washed with brine, dried over anhydrous $\mathrm{Na}_{2} \mathrm{SO}_{4}$, filtered, and concentrated. The crude product was purified by recycling HPLC to afford $130 \mathrm{mg}(85 \%)$ of ionophore 2. $\lambda_{\max } / \mathrm{nm}$ $\left(\mathrm{CH}_{3} \mathrm{CN}\right)\left(\varepsilon / \mathrm{M}^{-1} \mathrm{~cm}^{-1}\right): 276(23400), 312$ (12600), 326 (25100), 342 (35500); ${ }^{1} \mathrm{H}-$ NMR: $\delta=0.86\left(3 \mathrm{H}, \mathrm{t}, J=7 \mathrm{~Hz}, \mathrm{CH}_{3}\right), 0.87$ $\left(6 \mathrm{H}, \mathrm{t}, J=7 \mathrm{~Hz}, \mathrm{CH}_{3}\right), 1.40-1.47(6 \mathrm{H}, \mathrm{m}$, $\left.\mathrm{CH}_{2} \mathrm{CH}_{3}\right), 1.52-1.60\left(6 \mathrm{H}, \mathrm{m}, \mathrm{CH}_{2} \mathrm{CH}_{2} \mathrm{CH}_{3}\right)$, 2.18 (2H, quintet, $J=7 \mathrm{~Hz}, \mathrm{Py}_{-} \mathrm{CH}_{2} \mathrm{CH}_{2}$ ), $2.54\left(2 \mathrm{H}, \mathrm{t}, \mathrm{J}=7 \mathrm{~Hz}, \mathrm{OCOCH}_{2}\right), 2.81-2.86$ $\left(4 \mathrm{H}, \mathrm{m}, \mathrm{ArCH}_{2} \mathrm{CH}_{2}\right), 2.86-2.93(2 \mathrm{H}, \mathrm{m}$, $\left.\mathrm{ArCH}_{2} \mathrm{CH}_{2}\right), 3.36(2 \mathrm{H}, \mathrm{t}, J=7 \mathrm{~Hz}, \mathrm{Py}-$ $\left.\mathrm{CH}_{2}\right), 5.33\left(2 \mathrm{H}, \mathrm{s}, \mathrm{CH}_{2} \mathrm{OCOCH}_{2}\right), 5.53$ and $5.51\left(4 \mathrm{H}, \mathrm{s}, \mathrm{CH}_{2} \mathrm{OCOAr}\right), 7.77-8.13$ $(17 \mathrm{H}, \mathrm{m}, \mathrm{Ar}$ and Py).; ESI-MS 1093 $\left(\mathrm{M}+2 \mathrm{MeOH}+\mathrm{Na}^{+}\right)$.

\section{Results and Discussion}

\subsection{Design of Fluoroionophore 2}

The fluoroionophore 2 having a hexasubstituted benzene structure was synthesizedfrom 1,3,5-tributyl-2,4,6-tris(hydroxymetyl)benzene [29] via intermediate 3. Three butyl groups in the 1,3,5-positions were introduced not only for the effect of preorganization [38] but also to increase the lipophilicity of the ionophore in order to prevent leaching from the ISE/optode membrane. The observed lipophilicity parameter $\left(\log P_{\mathrm{O} / \mathrm{W}}\right)$ of 2 was 8.2 , which almost satisfies the required value for optode measurements in an aqueous system [49]. The result of a molecular modeling study is presented in Figs. 2a and 2b. Because the pyrenyl group is connected by relatively flexible ester and propylene units, this fluorescent unit is presumably pinched by two trifluoroacetophenone groups due to intramolecular interaction of the aromatic rings in the absence of the amino acid guest. Thus fluorescence response is expected by complexation with the anionic form of amino acids through reversible but stronger bond formation, which will induce conformational changes of the pyrenyl group as illustrated in Fig. 2c.

\subsection{ISE Performance of the Mem- brane Based on 1 and 2}

In the first stage, the concept of molecular design for amino acid binding was confirmed by a potentiometric study. We have found that the electrode based on 1 using $o$ NPOE as the membrane solvent shows bet- 
(a)

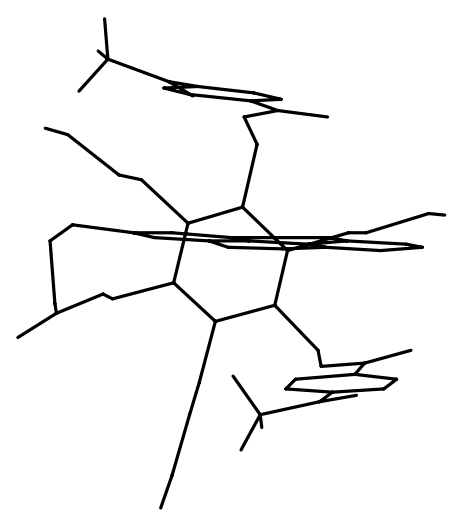

(c)

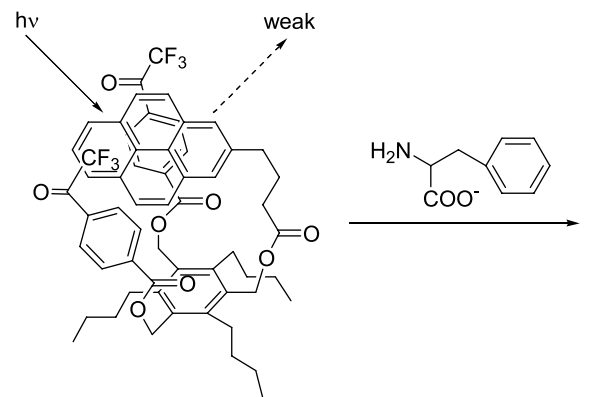

(b)
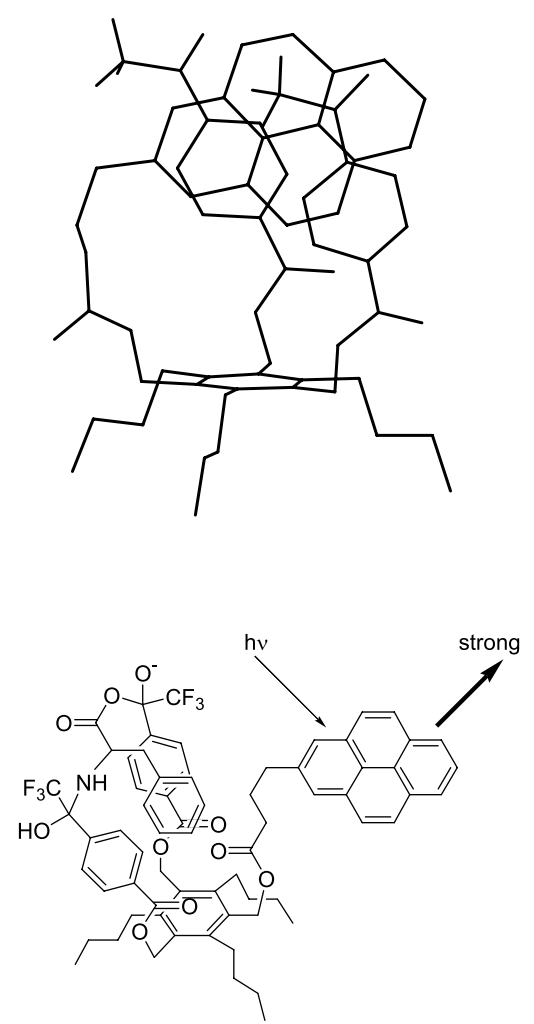

anionic Nernstian response $(\approx-59 \mathrm{mV} / \mathrm{de}-$ cade) toward phenylalanine, supporting the assumption that the two trifluoroacetophenone groups in $\mathbf{2}$ are sufficient for the simultaneous binding of the amino and carboxylate groups of anionic form phenylalanine. Almost the same detection limit and selectivity towards other interfering anions was observed for both electrodes, and the characteristics of the tripodal ionophore 2 turned out to be essentially the same as those of ionophore 1 having three binding sites.

Inspired by recent research work for cysteine determination [16][23][25][28], the performance of both electrodes in saturated cysteine/cystine buffer solution was also examined. When a $0.1 \mathrm{M}$ solution of cysteine in $0.1 \mathrm{M}$ Tris-buffer adjusted to $\mathrm{pH}=8.6$ was left on standing, a large amount of precipitate appeared within a few minutes, probably due to the formation of less soluble cystine under such aqueous alkaline conditions. Thus the upper solution was subjected to ISE measurement. The observed negative response shows that anionic species are extracted into the membrane. The relatively high apparent selectivity suggests that the thiol group capable of forming adducts with the trifluoroacetophenone moiety contributes to the formation of the ionophore-guest complex in competition with the $\alpha$-amino group to carboxylate.

Fig. 2. Schematic presentation of (a) top and (b) side view of fluoroionophore $\mathbf{2}$, where hydrogen atoms are omitted for clarity, and (c) a proposed mechanism of fluorescence response of $\mathbf{2}$ by complex formation with anionic form phenylalanine

ter performance than previously reported for DOS [29]. Therefore, experiments with the ISEs based on fluoroionophore 2 were carried out under these improved measurement conditions, and compared to those of ionophore 1. Fig. 3 shows the response curves of the electrodes based on $\mathbf{1}$ and $\mathbf{2}$ to phenylalanine, and their selectivity coefficients towards several amino acids and organic/inorganic anions are summarized in the Table. Both electrodes show mono-

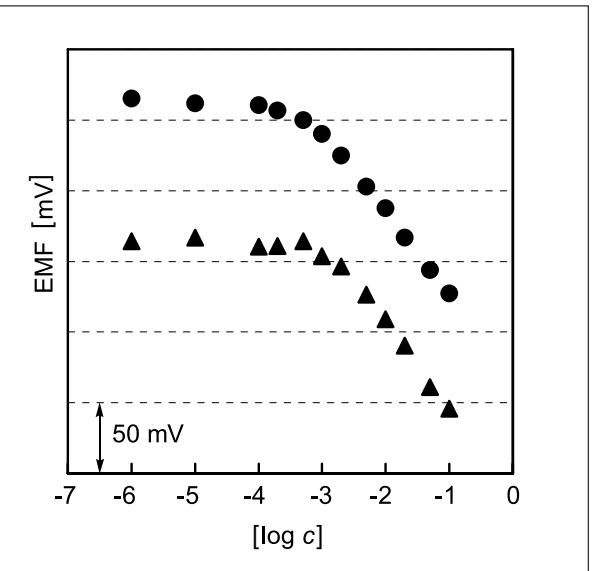

Fig. 3. EMF response curves of the electrodes based on ionophores $\mathbf{1}(\bullet)$ and 2 (४) to phenylalanine
Table. Potentiometric selectivity coefficients $\left(\log K_{i j}{ }^{\text {pot }}, i=\right.$ Phe) of the electrodes based on ionophores 1 and 2 for several amino acids ${ }^{a}$

\begin{tabular}{|c|c|c|c|c|c|}
\hline Amino acid & $1^{b}$ & 2 & Anions & 1 & 2 \\
\hline glycine & $-2.0(-1.7)$ & -1.7 & $\mathrm{~F}^{-}$ & -2.2 & -2.0 \\
\hline alanine & $-2.2(-1.7)$ & -1.9 & $\mathrm{Cl}^{-}$ & -2.3 & -1.9 \\
\hline valine & $-1.6(-1.3)$ & -1.6 & $\mathrm{Br}$ & -2.2 & -2.0 \\
\hline leucine & $-1.3(-0.9)$ & -1.3 & $\mathrm{I}^{-}$ & -1.1 & -0.9 \\
\hline isoleucine & $-1.1(-0.9)$ & -1.1 & $\mathrm{HPO}_{4}{ }^{2-}$ & -3.0 & -2.5 \\
\hline serine & $-2.1(-1.7)$ & -1.8 & $\mathrm{SO}_{4}{ }^{2-}$ & -3.1 & -2.1 \\
\hline threonine & $-2.1(-1.7)$ & -1.8 & $\mathrm{NO}_{2}^{-}$ & -1.8 & -1.5 \\
\hline methionine & $-1.1(-0.9)$ & -1.0 & $\mathrm{NO}_{3}^{-}$ & -1.4 & -1.1 \\
\hline proline & $-2.4(-1.8)$ & -1.8 & $\mathrm{SCN}^{-}$ & -0.5 & -0.2 \\
\hline histidine & $-2.1(-1.8)$ & -1.7 & $\mathrm{ClO}_{4}^{-}$ & 0.7 & 0.9 \\
\hline lysine & $-2.2(-1.9)$ & -2.1 & acetate & -2.0 & -1.8 \\
\hline arginine & $-2.0(-1.7)$ & -1.9 & benzoate & 0 & 0.3 \\
\hline asparagine & $-2.2(-1.4)$ & -1.8 & salicylate & 1.3 & 1.6 \\
\hline glutamine & $-2.2(-1.1)$ & -1.8 & & & \\
\hline cysteine $^{c}$ & -0.14 & -0.3 & & & \\
\hline
\end{tabular}

aThe selectivity coefficients were calculated from the response potentials to $0.1 \mathrm{M}$ sample solutions using the separate solution method (SSM)

bValues in parentheses are from [29], where the electrode membrane consisted of $3 \mathrm{wt} \%$ ionophore 1, $67 \mathrm{wt} \% \mathrm{DOS}, 30 \mathrm{wt} \% \mathrm{PVC}$, and $50 \mathrm{~mol} \%$ of TDDMACl relative to 1

'Saturated solution of cysteine in $0.1 \mathrm{M}$ Tris- $\mathrm{H}_{2} \mathrm{SO}_{4}$ buffer was measured 


\subsection{Spectroscopic Properties of Fluoroionophore 2}

The absorption and emission spectra of fluoroionophore 2 in acetonitrile are shown in Figs. 4a and 4b, respectively. Because amino acids are barely soluble in organic solvents, solid-liquid extraction was performed. Absorption spectral change did not occur with addition of amino acids, while fluorescence enhancement was observed after extraction. The increase of the fluorescence intensity is in the order of phenylalanine, cysteine, and glycine. The observed selectivity seems to be consistent with the lipophilicity of each amino acid. Since cystine did not cause any fluorescence increase, it is assumed that the thiol group of cysteine might have an advantage to form a neutral complex with 2 in this organic medium.

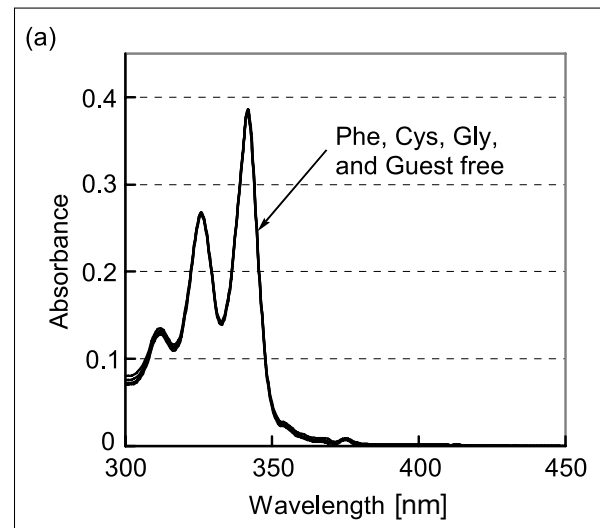

(b)

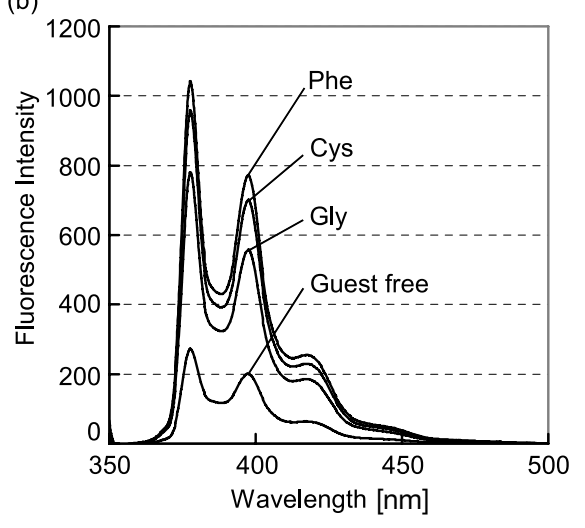

Fig. 4. (a) Absorption and (b) fluorescence spectra of fluoroionophore 2 in the presence of several amino acids in acetonitrile. [2] $=1.1 \times 10^{-5}$ M. Excitation wavelength: $342 \mathrm{~nm}$. Each solid amino acid was extracted with a solution of $\mathbf{2}$ and subjected to spectral measurements.

On the other hand, an optode membrane based on 2 was prepared using $o$-CPOE instead of $o$-NPOE as the membrane solvent for its optical transparency down to 320 $\mathrm{nm}$. When continuously excited at $347 \mathrm{~nm}$ under a flow of buffer solution, the fluorescence intensity decreased uniformly as demonstrated in Fig. 5. It was found that the

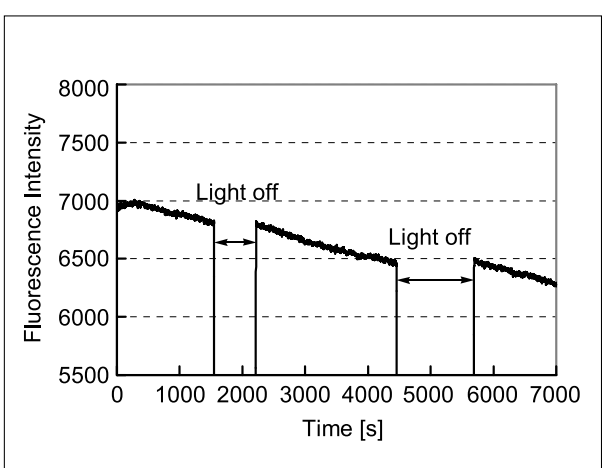

Fig. 5. Continuous monitoring of the fluorescence emission intensity of an optode membrane based on fluoroionophore 2. $50 \mathrm{mM}$ Tris $-\mathrm{H}_{2} \mathrm{SO}_{4}$ buffer solution adjusted to $\mathrm{pH}=8.6$ was flowed at a rate of $1.0 \mathrm{ml} / \mathrm{min}$, and the fluorescence intensity at $379 \mathrm{~nm}$ was monitored with the excitation wavelength of $347 \mathrm{~nm}$.

degree of photobleaching of this membrane was about $30 \%$ after continuous exposure to excitation light for $12 \mathrm{~h}$.

Fig. 6 shows the fluorescence spectral changes upon addition of different concentrations of cysteine buffer solution. Because the optode membrane did not immediately respond to the sample solutions, the shown spectra were recorded 6 min after injection. The relatively slow response time can partly be explained by the high viscosity of the polymeric optode membrane, resulting in reduced diffusion of the sample amino acid. Throughout the experiments, a higher ratio of PVC/ $o$-CPOE was applied compared to ISE membranes in order to increase the mechanical stability and the endurance of the sensor. Although the membrane responds to both phenylalanine and cysteine with a fluorescence enhancement as the concentration increases, it should be noted that cysteine causes a stronger response in this optode system. In Fig. 7, the fluorescence increase ratio $\left(\mathrm{F} / \mathrm{F}_{\mathrm{O}}\right)$ is plotted for several amino acids, where the initial and the observed fluorescence intensities are $\mathrm{F}_{\mathrm{O}}$ and $\mathrm{F}$, respectively. The selectivity for the various amino acids of this optode membrane is determined by comparing the signal intensity increase $5 \mathrm{~min}$ after sample injection as follows: Cys $11 \%$, Phe $7 \%$, Ile $6 \%$, Gly $3 \%$, His $1 \%$, Thr $1 \%$, Pro $1 \%$, Gln $0 \%$, Lys $0 \%$. The observed tendency of selectivity towards Cys, Phe, and Ile over other hydrophilic amino acids is consistent with the results obtained with the corresponding ISE membrane. Since the optode membrane is expected to respond to both anionic and neutral species as investigated by the solid-liquid extraction experiment, the apparent selectivity toward cysteine is partially ascribable to its thiol group allowing for the formation of a neutral complex which is more easily extracted into the optode membrane.

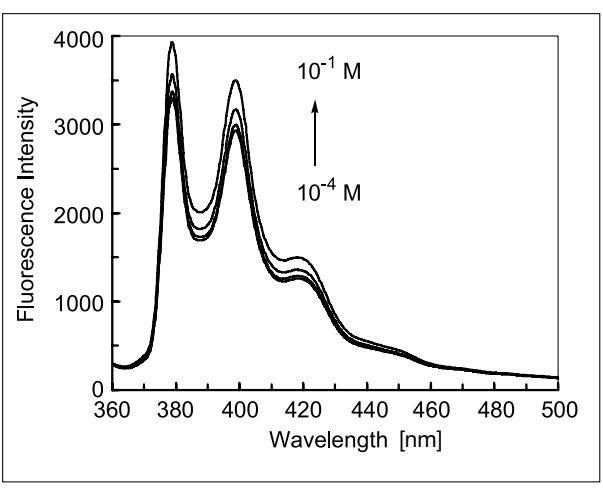

Fig. 6. Fluorescence spectra of an optode membrane based on fluoroionophore 2 upon the addition of several concentrations of cysteine $\left(10^{-4}, 10^{-3}, 10^{-2} \mathrm{M}\right.$, and saturated) solution adjusted to $\mathrm{pH}=8.6$ in $50 \mathrm{mM}$ Tris- $\mathrm{H}_{2} \mathrm{SO}_{4}$ buffer. Each spectrum was recorded 6 min after sample injection.

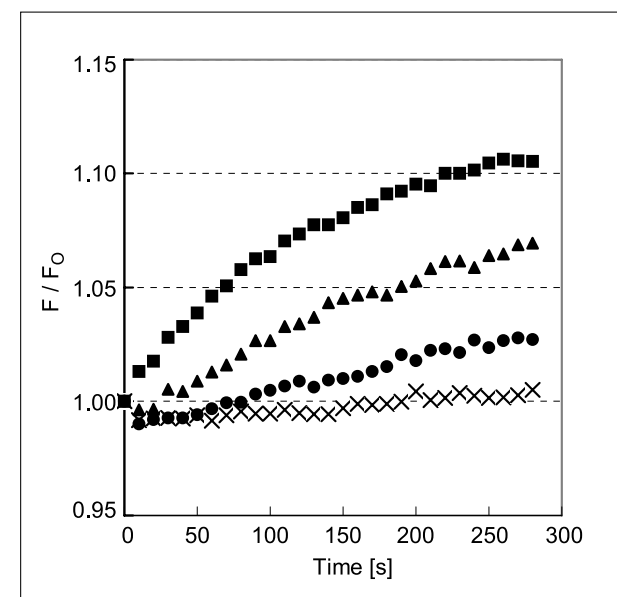

Fig. 7. Relative fluorescence intensity changes at $399 \mathrm{~nm}$ of an optode membrane based on fluoroionophore $\mathbf{2}$ upon the addition of $(\mathbf{\bullet})$ glycine, $(\boldsymbol{\Delta})$ phenylalanine, $(\boldsymbol{\square})$ cysteine, and $(x)$ without amino acid. $0.1 \mathrm{M}$ amino acid solutions adjusted to $\mathrm{pH}=8.6$ in $50 \mathrm{mM}$ Tris $-\mathrm{H}_{2} \mathrm{SO}_{4}$ buffer were flowed at a rate of $1.0 \mathrm{ml} / \mathrm{min}$. Excitation wavelength: $347 \mathrm{~nm}$.

\section{Conclusion}

We have demonstrated an example of design and synthesis of a fluoroionophore for underivatized amino acid sensing. It is shown that the ionophore can be used as a fluorogenic reagent for the detection of several amino acids in acetonitrile with fluorescence enhancement response. Furthermore, the ionophore was successfully applied to chemical sensors. The ISE based on $\mathbf{2}$ is the best phenylalanine selective electrode developed to date. Although the optode membrane still requires further improvement such as the reduction of photobleaching or the response time, the developed flow-system can optically detect several amino acids in buffered aqueous solution with fluorescence enhancement. The presented concept of molecular design based on trifluoroacetophenone derivatives 
intramolecularly combined with a fluorescent group is effective for amino acid sensing and is a first step in the development of new fluoroionophores for biologically related peptides.

Received: February 8, 2005

[1] U.E. Spichiger, 'Chemical Sensors and Biosensors for Medical and Biological Applications', Wiley-VCH, Weinheim, 1998.

[2] P. Bühlmann, E. Pretsch, E. Bakker, Chem. Rev. 1998, 98, 1593.

[3] P.D. Beer, P.A. Gale, Angew. Chem. Int. Ed. 2001, 40, 487.

[4] R. Martinez-Manez, F. Sancenon, Chem. Rev. 2003, 103, 4419.

[5] F.P. Schmidtchen, J. Org. Chem. 1986, 51, 5161.

[6] A. Galán, D. Andreu, A.M. Echavarren, P. Prados, J. de Mendoza, J. Am. Chem. Soc. 1992, 114, 1511.

[7] A. Metzger, K. Gloe, H. Stephan, F.P. Schmidtchen, J. Org. Chem. 1996, 61, 2051.

[8] M.D. Barboiu, N.D. Hovnanian, C. Luca, L. Cot, Tetrahedron 1999, 55, 9221.

[9] J. Chin, S.S. Lee, K.J. Lee, S. Park, D.H. Kim, Nature 1999, 401, 254.

[10] P. Breccia, M. Van Gool, R. Perez-Fernandez, S. Martin-Santamaria, F. Gago, P. Prados, J.C. de Mendoza, J. Am. Chem. Soc. 2003, 125, 8270.

[11] K. Tsubaki, H. Tanaka, H. Morikawa, K. Fuji, Tetrahedron Lett. 2003, 59, 3195.

[12] U. Pichler, P. Scrimin, P. Tecilla, U. Tonellaro, A. Veronese, M. Verzini, Tetrahedron Lett. 2004, 45, 1643.

[13] H. Aït-Haddon, S.L. Wiskur, V.M. Lynch, E.V. Anslyn, J. Am. Chem. Soc. 2001, 123, 11296.

[14] H. Imai, K. Misawa, H. Munakata, Y. Uemori, Chem. Lett. 2001, 688.

[15] W.H. Wang, J.D. Escobedo, C.M. Lawrence, R.M. Strongin, J. Am. Chem. Soc. 2004, 126, 3400.
[16] O. Rusin, N.N. StLuce, R.A. Agbaria, J.O Escobedo, S. Jiang, I. M. Warner, F.B. Dawan, K. Lian, R.M. Strongin, J. Am. Chem. Soc. 2004, 126, 438.

[17] A.P. de Silva, H.Q.N. Gunaratne, C. McVeigh, G.E.M. Maguire, P.R.S. Maxwell, E. O'Hanlon, Chem. Commun. 1996 , 2191.

[18] L. Fabbrizzi, M. Licchelli, A. Perotti, A. Poggi, G. Rabaioli, D. Sacchi, A. Taglietti, J. Chem. Soc., Perkin Trans. 2 2001, 2108.

[19] S. Sasaki, A. Hashizume, D. Citterio, E. Fujii, K. Suzuki, Tetrahedron Lett. 2002 , 43, 7243.

[20] M.A. Hortalá, L. Fabbrizzi, N. Marcotte, F. Stomeo, A. Taglietti, J. Am. Chem. Soc. 2003, 125, 20.

[21] E.K. Feuster, T.E. Glass, J. Am. Chem. Soc. 2003, 125, 16174.

[22] K.E.S. Dean, G. Klein, O. Renaudet, J.-L. Reymond, Bioorg. Med. Chem. 2003, 13, 1653.

[23] F. Tanaka, N. Mase, C.F. Barbas III, Chem. Commun. 2004, 1762.

[24] H. Tsukube, S. Shinoda, H. Tamiaki, Coord. Chem. Rev. 2002, 226, 227.

[25] H. Tsukube, N. Tameshige, S. Shinoda, S. Unno, H. Tamiaki, Chem. Commun. 2002 , 2574.

[26] H. Tamiaki, S. Unno, E. Takeuchi, N. Tameshige, S. Shinoda, H. Tsukube, $T e-$ trahedron 2003, 59, 10477.

[27] M.K. Amini, S. Shahrokhian, S. Tangestaninejad, Anal. Chem. 1999, 71, 2502.

[28] S. Shahrokhian, Anal. Chem. 2001, 73, 5972.

[29] S. Sasaki, A. Hashizume, D. Citterio, E. Fujii, K. Suzuki, Angew. Chem. Int. Ed. 2002, 41, 3005

[30] R. Yang, K. Wang, L. Long, D. Xiao, X Yang, W. Tan, Anal. Chem. 2002, 74, 1088.

[31] G.J. Mohr, C. Demuth, U.E. SpichigerKeller, Anal. Chem. 1998, 70, 3868.

[32] G.J. Mohr, I. Klimant, U.E. SpichigerKeller, O. S. Wolfbeis, Anal. Chem. 2001, 73, 1053.
[33] E. Mertz, S.C. Zimmerman, J. Am. Chem. Soc. 2003, 125, 3424.

[34] E. Mertz, J.B. Beil, S.C. Zimmerman, Org. Lett. 2003, 5, 3127.

[35] G.J. Mohr, D. Citterio, U.E. SpichigerKeller, Sens. Actuators B, Chem. 1998 49, 226.

[36] M.E. Meyerhoff, E. Pretsch, D.H. Welti, W. Simon, Anal. Chem. 1987, 59, 144.

[37] H.J. Lee, I.J. Yoon, C.L. Yoo, H.-J. Pyun, G.S. Cha, H. Nam, Anal. Chem. 2000, 72, 4694.

[38] D.J. Iverson, G. Hunter, J.F. Blount, J.R. Damewood, Jr., K. Mislow, J. Am. Chem. Soc. 1981, 103, 6073.

[39] A. Metzger, V.M. Lynch, E.V. Anslyn, Angew. Chem. Int. Ed. 1997, 36, 862.

[40] S.E. Schneider, S.N. O'Neil, E.V. Anslyn, J. Am. Chem. Soc. 2000, 122, 542.

[41] L.A. Cabell, M.D. Best, J.J. Lavigne, S.E. Schneider, D.M. Perreault, M.-K. Monahan, E.V. Anslyn, J. Chem. Soc., Perkin Trans. 2 2001, 315.

[42] S. Sasaki, S. Ozawa, D. Citterio, K. Suzuki, J. Chem. Soc., Perkin Trans. 22001 , 2309.

[43] J. Chin, C. Walsdorff, B. Stranix, J. Oh, H.J. Chung, S.-M. Park, K. Kim, Angew. Chem. Int. Ed. 1999, 38, 2756.

[44] S. Sasaki, T. Amano, G. Monma, G. Otsuka, N. Iwasawa, D. Citterio, H. Hisamoto, K. Suzuki, Anal. Chem. 2002, 74, 4845.

[45] J. Chin, J. Oh, S.Y. Jon, S.H. Park, C. Walsdorff, B. Stranix, A. Ghoussoub, S.J. Lee, H.-J. Chung, S.-M. Park, K. Kim, J. Am. Chem. Soc. 2002, 124, 5374.

[46] C. Behringer, B. Lehmann, J.P. Haug, K. Seiler, W.E. Morf, K. Hartman, W. Simon, Anal. Chim. Acta 1990, 233, 41.

[47] IUPAC recommendation for nomenclature of ion-selective electrodes, Pure Appl. Chem. 1976, 48, 127.

[48] JIS K-0122, Japanese Standards Association, Tokyo, 1997.

[49] O. Dinten, U.E. Spichiger, N. Chaniotakis, P. Gehrig, B. Rusterholz, W.E. Morf, W. Simon, Anal. Chem. 1991, 63, 596. 